\title{
EFFECT OF TWO METHODS OF SUCKLING ON THE YIELD OF MILK AND THE PERFORMANCE OF CALVES
}

\author{
THALATHA C. RATNAYAKE AND K.K. PATHIRANA
}

Department of Animal Science, Faculty of Agriculture, University of Rubuna, Kamburupitiya, Sri Lanka.

(Date of receipt : 27 February 1986)

(Date of acceptance : 17 March 1988)

Methods of milking influence the milk yield of a cow to a great extent. To obtain a high milk yield throughout a lactation, milking should be done quickly, quietly, cleanly and completely. Complete milking is very important and the calf could be introduced after milking to ensure that each quarter is completely milked. In Zebu crossbred cows suckling to stimulate milking seems particularly beneficial. ${ }^{3}$

Except for a few reports ${ }^{2,3}$ much data are not available on the effect of different methods of suckling on the performance of cows and calves.

The present study was to find out the effect of two methods of suckling combined with two methods of milking on the performance of the cows and calves.

Eight matched cross bred (indigenous $\mathrm{x}$ Sindhi and indigenous x Jersey) cow/calf pairs were selected for the experiment. The cows were $6.6 \pm 2.9$ $(\overline{\mathrm{X}} \pm \mathrm{SD})$ years old weighing $231.3 \pm 38.1 \mathrm{~kg}$. Their calves were $2.4 \pm 0.3$ months old with a live weight of $33.8 \pm 12.9 \mathrm{~kg}$.

The study consisted of two phases: (1) a preliminary phase consisting of three investigations to study the existing milking practices at farm, and (2) an experimental phase to compare the two methods of suckling and milking. Eight selected cow/calf pairs were used thoughout the study. But for the second phase, calves were evenly grouped into four pairs so that within each pair the animals were uniform. Animals in each pair were then divided into two groups with their dams so that the two groups were similar in live weight and age. There were two treatments. In one, all four quarters were completely milked (4Q) and in the other, only three quarters were completely milked leaving the fourth to the calf (3Q). The quarter to be unmilked in $3 \mathrm{Q}$ was rotated weekly among the four quarters during each month for the two experimental periods. In both treatments, calves were allowed to suckle all four quarters after milking. Before milking, suckling was used only as a stimulus for milk let-down as judged by the engorgement of teats. A simple change-over design was used to test the two treatments. 
Two groups of experimental calves were kept in two separate pens, except at milking. In addition to the feeding of milk (through suckling only), concentrates ( $15 \%$ crude protein), Brachiaria brizantha ( $12.5 \%$ crude protein) and water for drinking were provided ad libitum. Proximate analysis of grass was determined according to A.O.A.C. (1975).

The cows were milked twice daily by hand. After milking in the morning cows were allowed to graze on natural pasture until they were milked in the afternoon and then kept in a small enclosure for the night without feed.

\section{Preliminary Phase}

\subsection{First preliminary investigation}

Different stages and timing of the existing once a day milking practices of the farm, as recorded with all the animals to be included in the experiment are given in Table 1. Time of suckling required to stimulate milk let-down judged from the engorgement of teats was less before than after the first milking (Table 1, item 1 vs 5 ). As would be expected, the duration of milking until the quarter was empty was greater at first than at the second milking (item 3 vs 7 ). The entire milking operation took $13.08 \pm 2.17 \mathrm{~min}$. (range 5.71 to $24.24 \mathrm{~min}$ ) which tended to be greater than the normally accepted duration of the effect of oxytocin. 
Table 1. Different stages and timing (minutes) of the existing once a day milking practices ${ }^{\mathrm{a}}$.

Operation in Range

chronological order

$\min$

$\max$

$\overline{\mathbf{X}} \pm \mathrm{SD}$

1. Duration of 1 st suckling prestimulus

1.00

2.45

$1.26 \pm 0.17$

2. Duration from end of 1st suckling to begining of 1st milking .40

$0.31 \pm 0.04$

3. Duration of 1 st milking

9.49

$5.52 \pm 1.37$

4. Duration from end of 1 st milking to 2 nd introduction of calf

.04

.25

$0.09 \pm 0.04$

5. Duration of 2 nd suckling prestimulus

5.15

$1.97 \pm 0.53$

6. Duration from end of 2nd suckling to milking

7.. Duration of 2 nd milking

8. Total time

a

Each value is a mean of 24 observations ( 8 cow/calf pairs $\times 3$ observations during morning milking on 3 consecutive days) 


\subsection{Second preliminary investigation}

Data on the effect of suckling prestimulus on milk yield are given in Table 2. Without a suckling prestimulus the milk yield was only $4.49 \%$ that of the cows which were suckled before milking. The necessity for the presence of the calf for proper milk let-down in indigenous cows is thus confirmed.

Table 2. Effect of suckling on the amount of milk let-down ${ }^{\mathrm{a}}$

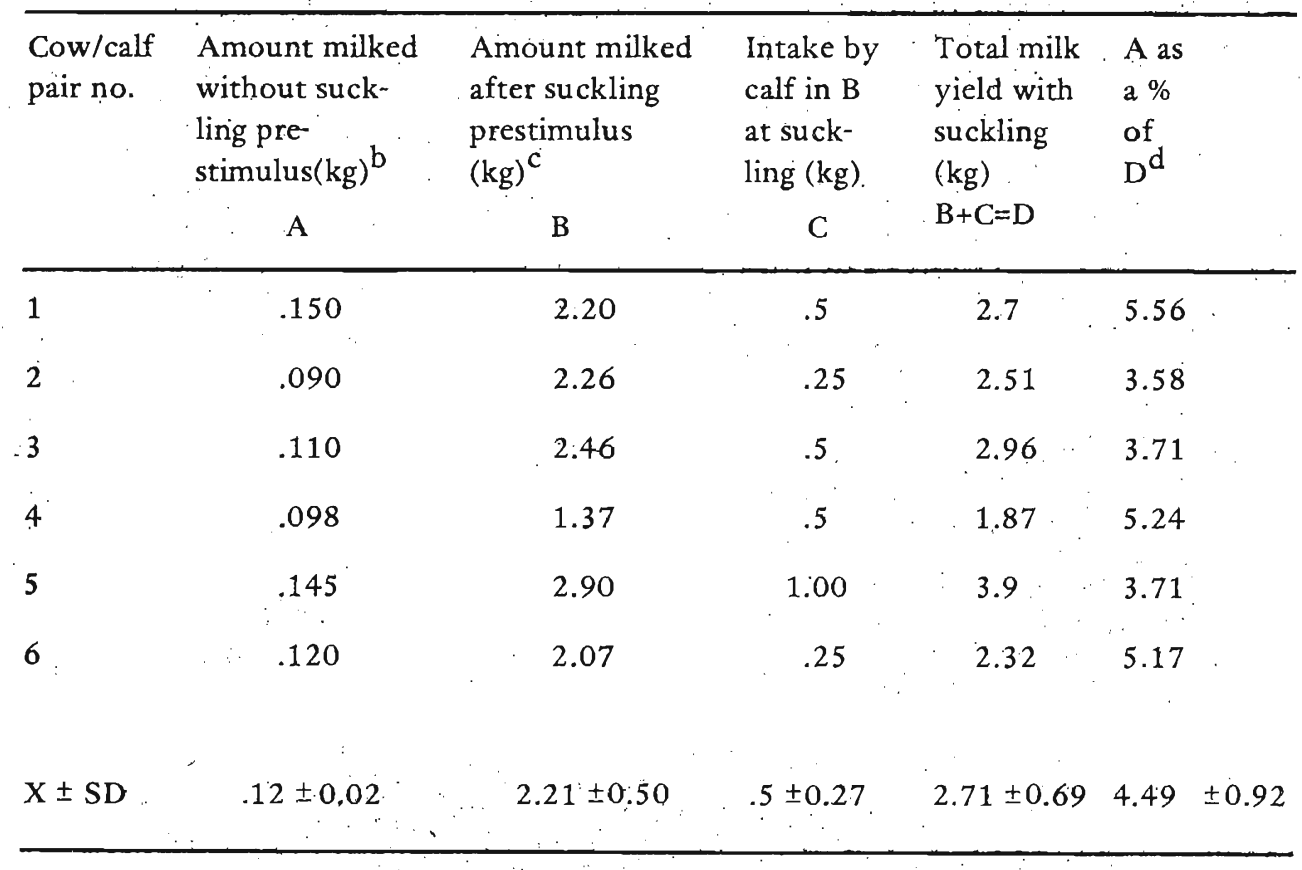

a

The sequence was : suckling, milking, suckling and milking

$\mathrm{b}$

Without calves

c

With calves

d

Amount milked without calves for suckling prestimulus as a percentage of the total milk yield (amount milked plus intake by calf) with suckling prestimulus. 


\subsection{Third preliminary investigation}

The results are presented in Table 3. There was an average of $40.13 \pm 10.54 \%$ increase in the milk yield due to twice a day milking as compared to once a day milking. Increasing the frequency of milking from twice a day to three and four times a day has also increased the milk yield of cows by $10-25 \%$ and $5-15 \%$, respectively. ${ }^{1}$. This tendency is in agreement with the present findings.

Table 3. Effect of milking frequency on milk yield

\begin{tabular}{|c|c|c|c|c|c|c|c|}
\hline \multirow{3}{*}{$\begin{array}{l}\text { Cow/calf } \\
\text { pair no. }\end{array}$} & \multirow{2}{*}{\multicolumn{2}{|c|}{ Amount milked }} & \multicolumn{4}{|c|}{ Amount of milk/cow/day $(\mathrm{kg})^{\mathrm{a}}$} & \multirow{3}{*}{$\begin{array}{l}\text { Increase of } \\
\text { twice a day } \\
\text { total over } \\
\text { once a day } \\
\text { total (\%) }\end{array}$} \\
\hline & & & \multicolumn{2}{|c|}{ Intake by calf } & \multicolumn{2}{|c|}{ Total } & \\
\hline & $\begin{array}{l}\text { once a } \\
\text { day }\end{array}$ & $\begin{array}{l}\text { twice a } \\
\text { day }\end{array}$ & $\begin{array}{l}\text { once a } \\
\text { day }\end{array}$ & $\begin{array}{l}\text { twice a } \\
\text { day }\end{array}$ & $\begin{array}{l}\text { once a } \\
\text { day }\end{array}$ & $\begin{array}{l}\text { twice a } \\
\text { day }\end{array}$ & \\
\hline 2 & 2.38 & 2.39 & 0.37 & 1.16 & 2.52 & 3.57 & 41.6 \\
\hline 3 & 2.40 & 2.38 & 0.50 & 1.66 & 2.91 & 4.06 & 39.5 \\
\hline 4 & 1.67 & 1.89 & 0.54 & 1.50 & 2.18 & 3.23 & 48.0 \\
\hline 6 & 3.10 & 3.39 & 0.79 & 1.25 & 3.89 & 4.71 & 21.0 \\
\hline 7 & 1.42 & 1.52 & 0.29 & 1.04 & 1.70 & 2.37 & 39.4 \\
\hline 8 & 2.50 & 3.01 & 0.54 & 1.66 & 3.04 & 4.60 & 51.3 \\
\hline $\bar{X}$ & 2.25 & 2.43 & 0.51 & $1: 38$ & 2.71 & 3.76 & 40.13 \\
\hline$\pm \mathrm{SD}$ & 0.61 & 0.69 & 0.17 & 0.27 & 0.76 & 0.89 & 10.54 \\
\hline
\end{tabular}

${ }^{a}$ Mean values of 6 days 


\subsection{Experimental Phase}

Proximate composition of forage (Brachiaria brizantha) offered is presented in Table 4. The protein content of forage was acceptable (12.51\%) by local standards and the dry matter (DM) content was as expected $(20.32 \pm 2.69 \%)$ The ad libitum intake of grass and concentrates by calves is presented in Table 5. The consumption of grass and concentrates by the calves or two treatments were approximately similar although they were offered $a d$ libitum. Total DM intake from grass and concentrates was satisfactory, being 2.71 to $2.93 \%$ live weight, where DNi intake from grass accounted for 2.25 to $2.41 \%$ live weight. On a fresh basis, the ad libitum intake of grass was about $5.5 \mathrm{~kg} / \mathrm{head} /$ day.

Table 4. Proximate Composition of Brachiaria brizantha ${ }^{\mathrm{a}}$

\begin{tabular}{ccccccc}
\hline $\begin{array}{l}\text { Experimental } \\
\text { period }\end{array}$ & D.M. \% & $\begin{array}{c}\text { Chemical composition (\%) on DM basis } \\
\text { Crude }\end{array}$ & E. E. & C. F. & Ash & N.F.E. \\
\hline 1 & $19.54 \pm 2.81$ & 12.25 & 2.96 & 26.11 & 7.16 & 51.52 \\
2 & $21.18 \pm 2.40$ & 12.77 & 2.15 & 25.52 & 6.77 & 52.89 \\
$\pi$ & $20.32 \pm 2.69$ & 12.51 & 2.56 & 25.82 & 6.97 & 52.14 \\
\hline
\end{tabular}

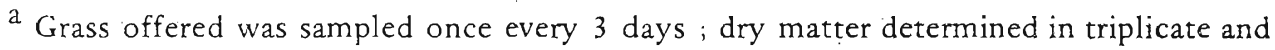
samples pooled within the two experimental periods for proximate analysis.

Table 5. Intake of Brachiaria brizantha and concentrates by calves on a DM basis $^{\mathrm{a}}$

\begin{tabular}{|c|c|c|c|c|c|c|}
\hline \multirow{2}{*}{$\begin{array}{l}\text { Dry matter } \\
\text { intake }\end{array}$} & \multicolumn{2}{|c|}{ Grass } & \multicolumn{2}{|c|}{ Concentrates } & \multicolumn{2}{|c|}{ Total } \\
\hline & $4 Q^{b}$ & $3 Q^{c}$ & $4 Q$ & $3 Q$ & $4 Q$ & $3 Q$ \\
\hline $\mathrm{kg} /$ head/day & & & & & & \\
\hline $\bar{X} \pm S D$ & $1.12 \pm 0.32$ & $1.17 \pm 0.52$ & $.24 \pm 0.22$ & $.25 \pm 0.14$ & 1.36 & 1.42 \\
\hline $\begin{array}{l}\% \text { Live } \\
\text { weight }(\bar{X})\end{array}$ & 2.25 & 2.41 & 0.46 & 0.52 & 2.71 & 2.93 \\
\hline
\end{tabular}

${ }^{a}$ Grass and concentrates were offered ad libitum and each value is a mean of 8 observations ( 4 weekly observations per experimental period $\times 2$ experimental periods). Intake measured on a group basis and divided by 4 to obtain per head intake.

$b_{\text {Four quarters milked }}$

${ }^{c}$ Three quarters milked 
Data on calf performance and milk yield are presented in Table 6. The method of milking and suckling had no significant effect $(p>.05)$ on any of the calf performance and milk yield data. Milking all four quarters (4Q) compared with the leaving of one quarter for the calf $(3 Q)$ tended to give a higher amount of milk in the bucket, but a reverse tendency in the intake of milk by the calf was noted as normally expected. Consequently the total amount of milk drawn was almost the same (3.68 vs 3.67 $\mathrm{kg} /$ cow $/ \mathrm{d}$ ) in the above two treatments. Although the intake of milk by calves was insufficient in $4 \mathrm{Q}$ and $3 \mathrm{Q}$ (3.39 and $3.65 \%$ live weight, respectively) the average daily gain (ADG) of calves was quite satisfactory by local standards. This máy have been at least due partly to the adequate intake of grass and concentrates by the calves.

In both treatments the calves were allowed to suckle before each of the two milkings at a milking session in order to stimulate milk let-down and were allowed ad libitum suckling only after two milkings were completed. If forages and concentrates of satisfactory quality are not available in required quantities, additional milk will have to be offered to the calves for satisfactory growth if the methods of suckling as done in this study are to be adopted.

All the cows were free of mastitis, which may have been partly due to suckling, since a lower incidence of mastitis due to suckling has been reported. The practice of suckling has also increased the total milk yield of cows. Considering the existing milking practices of the dairy herd, the practice of suckling is recommended to be continued. Twice a day instead of once a day milking, however, be adopted and calves kept back from dams at grazing while offering the calves ad libitum good quality forages and concentrates in the pens. 
Table 6. Data on calf performance and milk yield ${ }^{\mathrm{a}}$

\begin{tabular}{ccc}
\hline Irem & \multicolumn{2}{c}{ Treatments } \\
& $4 \mathrm{Q}$ & $3 \mathrm{Q}$ \\
\hline Milk in the bucket $(\mathrm{kg} / \mathrm{d})$ & $2.44 \pm 0.18$ & $2.29 \pm 0.23$ \\
Intake by calf: $(\mathrm{kg} / \mathrm{d})$ & $1.26 \pm 0.11$ & $1.39 \pm 0.11$ \\
$(\% \mathrm{LW})$ & $3.39 \pm 0.88$ & $3.65 \pm 0.86$ \\
Total milk $(\mathrm{kg} / \mathrm{d})$ & $3.68 \pm 0.23$ & $3.67 \pm 0.31$ \\
Live weight of calves $(\mathrm{kg}):$ & & \\
Initial & $47.32 \pm 7.12$ & $47.21 \pm 0.82$ \\
$\quad$ Final & $49.39 \pm 7.39$ & $49.24 \pm 6.95$ \\
A D G $(\mathrm{kg}) . \quad 0.30 \pm 0.05$ & $0.29 \pm 0.04$ \\
\hline
\end{tabular}

${ }^{a}$ Each value is a mean of 32 observations ( 4 cow/calf pairs $\times 2$ experimental periods $\times 4$ weekly intervals per experimental period based on records kept daily). ivene of the differences were signifịcant $(\mathrm{P}>.05)$.

$\mathrm{b}$ Average daily gain

\section{Acknowledgements}

The authors wish to thank Miss. I. D. Wickramasingha (Assistant Lecturer, of the Department) and Mr. A Kumarasiri (Farm Manager of the Faculty Farm) for their advice, help and providing of facilities for this study. The help of Mrs. S. F. B. N. Goonawardana (Assistant Lecturer of the Department of Agronomy) with the proximate analysis of the samples is also acknowledged.

\section{References}

1. BATH, D. L., DiCkinson, F. N. \& APPleman, H. A. (1972) Dairy cattle : Principles, Practices, Problems, Profits (2nd Ed.) Lea \& Febiger., Philadclphia.

2. EVERitT, G. C., PHillipS, S. D. M. \& WhitemaN, D. P. (1968) Suckling : Effect on̈ the calf and the cow. Proc., Ruakura Farmer's conf. weick, N.Z.

3. UGARTE, J. \& PRESTON, T. R. (1972). Rearing dairy calves by restricted suckling : 1. Effect of suckling once or twice daily on milk production and calf growth, Rev. Cuba. Gienc. Agric. (Engl. ed.) $6: 331$. 